\title{
The influence of electronic customer to customer interaction on customer loyalty
}

\author{
Xue jing ${ }^{1, a}$ and Xuewei ${ }^{2, b}$ \\ ${ }^{1}$ School of Economics and Management, Yunnan Open University, Kunming, 650223, China \\ ${ }^{2}$ School of Network and Adult Education, Yunnan Open University, Kunming, 650223, China

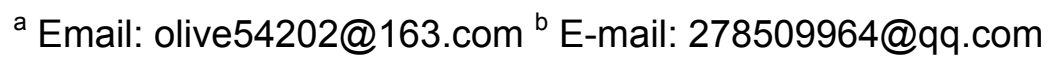

Keywords: big data environment, electronic customer to customer interaction, customer loyalty, perceived value, perceived risk

\begin{abstract}
This research constructed a conceptual model in which electronic customer to customer interaction influences their loyally through customer perceived value and perceived risks. Moreover, the measurement scale of relevant variables was established. The authors used the empirical research method to validate the scientificity and rationality of the conceptual model and analyzed the research results. This study provides an instructive insight for enterprise management.
\end{abstract}

\section{Introduction}

The research results of ECCI show that the interaction perception between customers exhibit dependence in different industries. Existing researches mainly concentrate on industries such as retain business, tourism and pay little attention on real estate. The real estate industry in China now attaches more importance to short-term profit. Although it increases rapidly, the satisfactory level is low. In contrast, the mature real estate enterprises at abroad place more stress on the significance of establishing favorable relationship between enterprise and customer. Their historical statistics suggest that the recommendation of old customers take up of great proportion of customer resources and turnover probability. Hence, increasing customer satisfactory level and loyalty are key factors of facilitating health development of real estate industry in China. At present, many studies have been performed on the satisfactory level and loyalty of the customers in real estate industry in China, however they mainly investigate the link between enterprises and customers and fail to consider the effect of the customer to customer link. Furthermore, they do not explore the effect of ECCI on customer loyalty.

\section{Theoretical hypothesis model and questionnaire design}

Based on the recognition of connotations of ECCI, perceived value, perceived risk and customer loyalty, and their relationships, the authors examine the characteristics of real estate industry. On this basis, this research constructs a relationship model for ECCI customer loyalty in real estate industry by referring some relevant literatures, as shown in figure 1. Figure shows the conceptual model for the influence of ECCI on customer loyalty.

By jointly using qualitative and quantitative investigations, based on existing researches and in-depth interview, the questionnaire is primarily designed. In the design process, the basic factors of the questionnaire consist of the variables of the measurement scale model and include four aspects: ECCI, perceived value, perceived risk, customer loyalty. 


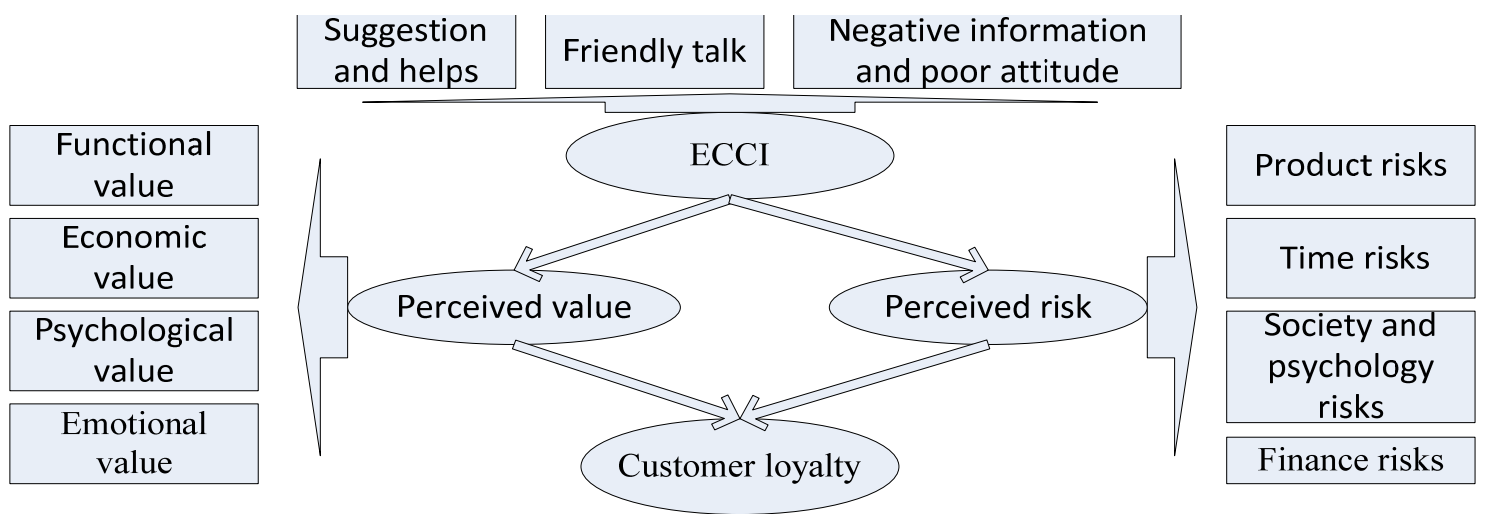

Figure 1 Conceptual model for the influence of ECCI on customer loyalty

\section{Data analysis and discussion}

\subsection{Collection of samples and data}

This research firstly conducts a questionnaire by taking real estate industry as the investigating objects. Prior to the investigation of large scale data, the newly decorated and moved buildings in Kunming were investigated in advance so as to validate the effectiveness of each index. In this way, the indexes can be purified to increase the reliability of questionnaire. In initial testing stage, we delivered 100 copies of questionnaires and collected 99 copies. Then SPSS19.0was used to process the data collected. The reliable analysis was performed to validate the reliability of the questionnaire. After deleting two CITC items which are lower than 0.5 , the rest of 43 items were conducted factor analysis using SPSS19.0. Results show the favorable structure validity. So there were 43 test items being determined in the questionnaire. Using the issuing the questionnaires via online, 200 customers of real estate ECCI were randomly selected and collected with 199 copies of effective ones.

\subsection{Data analysis and discussion}

SPSS19. 0 is firstly used to verify the reliability of form measurement scale. The measurement scale is proved to be reliable. Afterwards, the Confirmatory factor analysis was carried out to confirm the validity. The results indicate strong convergence validation of the measuring model. Meanwhile, the Average variances extracted(AVE) of each concept in this research are all greater than 0.5 , which meeting the requirements of each concepts on AVE.

A structure equation model AMOS17. 0 was used to calculate the fitting indexes and estimated values of coefficient of each path by using maximum likelihood estimation. The research obtained the relationship among relevant latent variables assumed. Results indicate that in the index fitting using structure equation model, almost all fitting indexes are all higher than the critical values suggested in existing researches except for the relevant fitting index NFI $=0.896$ which is slightly smaller than 0.90. In general, the assumed model and fitting degree of the data in this research are satisfactory. The estimated values of main parameters is of statistics significance, which proving the higher fitting degree of the conceptual model and the data.

The model was checked to confirm whether or not the estimating values of the parameters indicate the right symbols, size as well as support the assumption. The checked results are shown in table 1 and most of results are validated. The standard of testing the assumed relationship is described as: If the path relationship passes the test for a significant level at 0.05 , it stands, vice versa. 11 paths which are the influence suggestion and help on psychology, the influence of friendly talk on psychology, the influence of friendly talk on economic value, the influence of friendly talk on functional value, the influence of negative information and poor attitude on economic value, the influence of friendly talk on product risk, the influence of friendly talk on financial risk, the influence of negative information and poor attitude on time risk, the influence of time risk on customer loyalty, the influence of functional value on customer loyalty failed to pass the significant test. The rest of 21 assumptions were validated and supported. 
The research results abovementioned show that ECCI behaviors in real estate industry show positive or negative influences on customer loyalty through customers' perceived value and perceived risk.

1) Effect of ECCI on perceived value

In the big data context, ECCI is considered as one important influencing factor of customers' perceived value. Its external variables influence perceived value in different manners. Suggestion, help and friendly talk exhibit positive effect on partial dimension of perceived value. Among them, that suggestion and help dimensions are able to exert significant effect on emotional and psychological values of perceived value, while friendly talk, negative information and poor attitude mainly affect the emotional and psychological values of perceived value. The results suggest that the enterprises managers are expected to increase customers perceived value through creating more opportunities of providing suggestions and helps. This will greatly promote the economic and functional values perceived by customers, besides, they are suggested to build a friendly talk virtual environment, and take some measures to control negative information and poor attitude. By doing so, the emotional and psychological values will be greatly increased so as to increase overall customers' perceived value.

Table 1. The test results of the assumed paths in the model constructed

\begin{tabular}{|c|c|c|c|c|c|c|}
\hline Assumed Paths & Estimate & S.E. & C.R. & $\mathrm{P}$ & Label & Yes or No \\
\hline Suggestion and helps $->$ Emotional value & 0.155 & 0.067 & 2.331 & 0.02 & 0.217 & Yes \\
\hline $\begin{array}{c}\text { Suggestion and helps -> Psychological } \\
\text { values }\end{array}$ & 0.054 & 0.09 & 1.606 & 0.544 & 0.102 & No \\
\hline $\begin{array}{c}\text { Suggestion and helps -> Economic } \\
\text { values }\end{array}$ & 0.431 & 0.101 & 4.251 & $* * *$ & 0.506 & Yes \\
\hline $\begin{array}{c}\text { Suggestion and helps ->Functional } \\
\text { values }\end{array}$ & 0.945 & 0.069 & 0.692 & $* * *$ & 0.973 & Yes \\
\hline Friendly talk-> Emotional values & 0.414 & 0.068 & 6.093 & $* * *$ & 0.535 & Yes \\
\hline Friendly talk-> Psychological values & 0.136 & 0.071 & 1.907 & 0.057 & 0.235 & No \\
\hline Friendly talk-> Economic values & 0.009 & 0.075 & 0.114 & 0.909 & 0.009 & No \\
\hline Friendly talk-> Functional values & 0.043 & 0.041 & 1.062 & 0.288 & 0.041 & No \\
\hline $\begin{array}{l}\text { Negative information and poor attitude } \\
->\text { Emotional value }\end{array}$ & -0.275 & 0.09 & -3.054 & 0.002 & -0.316 & Yes \\
\hline $\begin{array}{l}\text { Negative information and poor attitude } \\
->\text { Psychological values }\end{array}$ & -0.205 & 0.119 & -1.722 & 0.085 & -0.314 & Yes \\
\hline $\begin{array}{c}\text { Negative information and poor attitude } \\
->\text { Economic values }\end{array}$ & -0.018 & 0.127 & -0.141 & 0.888 & -0.017 & No \\
\hline $\begin{array}{c}\text { Negative information and poor attitude } \\
->\text { Functional values }\end{array}$ & -0.045 & 0.069 & -0.644 & 0.519 & -0.038 & No \\
\hline Suggestion and helps -> Product risks & -0.773 & 0.102 & -6.575 & $* * *$ & -1.011 & Yes \\
\hline Suggestion and helps -> Finance risks & -0.74 & 0.13 & -5.682 & $* * *$ & -0.676 & Yes \\
\hline Suggestion and helps -> Society and & -0.295 & 0.101 & -2.915 & 0.004 & -0.361 & Yes \\
\hline Suggestion and helps ->Time risks & -0.365 & 0.118 & -3.102 & 0.002 & -0.356 & Yes \\
\hline Friendly talk-> Product risks & -0.279 & 0.062 & -1.273 & 0.203 & -0.085 & No \\
\hline Friendly talk-> Finance risks & -0.186 & 0.097 & -1.914 & 0.056 & -0.157 & No \\
\hline Friendly talk-> Society and psychology & -0.255 & 0.081 & -3.168 & 0.002 & -0.289 & Yes \\
\hline Friendly talk-> Time risks & -0.246 & 0.092 & -3.745 & $* * *$ & -0.312 & Yes \\
\hline $\begin{array}{c}\text { Negative information and poor attitude } \\
\rightarrow>\text { Product risks }\end{array}$ & 0.266 & 0.109 & 2.433 & 0.015 & 0.253 & Yes \\
\hline $\begin{array}{l}\text { Negative information and poor attitude } \\
->\text { Finance risks }\end{array}$ & 0.392 & 0.168 & 2.342 & 0.019 & 0.295 & Yes \\
\hline $\begin{array}{c}\text { Negative information and poor attitude } \\
->\text { Society and psychology risks }\end{array}$ & 0.124 & 0.131 & 0.949 & 0.043 & 0.125 & Yes \\
\hline $\begin{array}{l}\text { Negative information and poor attitude } \\
->\text { Time risks }\end{array}$ & 0.05 & 0.151 & 0.333 & 0.739 & 0.04 & No \\
\hline Product risks -> Customer loyalty & -0.142 & 0.109 & -1.304 & 0.021 & -0.192 & Yes \\
\hline Finance risks $->$ Customer loyalty & -0.224 & 0.056 & -0.423 & $* * *$ & -0.241 & Yes \\
\hline $\begin{array}{c}\text { Society and psychology risks -> } \\
\text { Customer loyalty }\end{array}$ & -0.324 & 0.188 & -1.728 & $* * *$ & -0.417 & Yes \\
\hline
\end{tabular}




\begin{tabular}{ccccccc}
\hline Time risks -> Customer loyalty & -0.210 & 0.143 & -0.07 & 0.944 & -0.016 & No \\
\hline Functional values -> Customer loyalty & 0.059 & 0.125 & 0.469 & 0.639 & 0.09 & No \\
\hline Economic values -> Customer loyalty & 0.17 & 0.072 & 1.95 & $* * *$ & 0.187 & Yes \\
\hline Psychological values -> Customer & 0.64 & 0.296 & 2.16 & $* * *$ & 0.539 & Yes \\
\hline Emotional value -> Customer loyalty & 0.405 & 0.21 & 1.924 & $* * *$ & 0.456 & Yes \\
\hline
\end{tabular}

2) Influence of ECCI on perceived risk

It is known that three dimensions of ECCI all exert influences on customers perceived risk to some extent. Among them, suggestion and help show significant negative influences on the four dimensions of perceived risk. Friendly talk presents prominent negative influence on psychosocial and time risks. The negative information and poor attitude show significant positive influence on risks in product, finance, society and psychology. It is concluded that suggestion and help indicate most prominent negative effect on perceived risk. Enterprise managers can decrease customers' perceived risks though providing more suggestion and helps in ECCI. Besides, they are recommended to decrease psychosocial and time risks by enhancing friendly talk in ECCI. Moreover, enterprises are expected to take effective measures to control the negative information and poor attitude in ECCI so as to reduce the risks in product, finance, society, and psychology.

3 ) Perceived value, perceived risk and customer loyalty

As shown in data analysis results in real estate consumption, the more the customers perceive economic, emotional and psychological values, the higher the customer loyalty. Meanwhile, the lower the risks in product, finance, society and psychology those customers perceive, the higher the customer loyalty. The conclusions shows that enterprise managers are suggested to increase the customer loyalty by making every effort to rising customers' perceived value and decreasing their perceived risk .

4) Electronic customer to customer interaction and customer loyalty

In summery, ECCI behaviors exert positive or negative influence on customer loyalty through customers' perceived value and perceived risk. Among the behaviors, suggestion, help and friendly talk are likely to indirectly present positive influence on customer loyalty. However, negative information and poor attitude show negative influence indirectly.

\section{Conclusion and prospects}

The analysis results show that ECCI behaviors influence customer loyalty by means of customers perceived value and perceived risk. Among which, perceived value indicates positive influence on customer loyalty while perceived risk shows negative influence on customer loyalty. In order to increase customer loyalty level in big data times, enterprises need to more focus the changes of emprises and customers resulting from the information technology, increase the channels of establishing relationship between customer and enterprise, create more opportunities of increasing customers' perceived value, and decrease the negative events of leading to customers' perceived risk. The future research is expected to further improve effect of the interactions between e-platform of enterprise and customer, as well as enterprises. In this way, the improving customer satisfactory level and service level can be realized to increase customer loyalty.

Supported by Research Fund of Yunnan Open University (No.2014Y014)

\section{References}

[1] Baldinger Allan L, Rubinson Joal. Brand Loyalty:The link between attitude and behacior[J]. Journal of Advertising Research, 1996, 11(2)22-24.

[2] Oliver Richard L. Satisfaction: A Behavioral Perspective on the Consumer[C]. New York, NY:Irwin-McGraw-Hill, 1997, 50-80.

[3] Zeitham I, Valarie A, Leonard Berry A. The Behacioral consequences of Sevice Quality[J]. Journal of Marketing, 1996, 60(4): 31-46. 
[4] Yu CH, Chang HC, Huadng GL. A Study of Service Quality,Customer Satisfaction and Loyalty in Taiwanese Leisure industry[J]. Journal of American Academy of Business, 2006, 9(1):126-132.

[5] Porter. Competitive advantage: creating and sustaining superior performance[M]. New York:The Free Press, 1985, 89-95.

[6] Woodruff. Customer value:the next source for competitive advantage[J].Journal of the Academy of Marketing Science, 1997, 25(2):139-153.

[7] Philip Kotler. Marketing Management[M]. Shanghai People's Publishing House, 2003, 169-178.

[8] William D Nee1. Satisfaction is Nice But Value Drives loyalty[J]. Marketing Research, 1996, 5(6):12-20.

[9] Bauer RA. Consumer Behavior as Risk Taking, Dynamic Marketing for A Changing World [C], R. S. Handcock, Chicago, AMA Proceedings, 1960, 389-98.

[10] Murray, Keith B, John L Schlacter. The Impact of Service Versus Goods on Consumers' Assessment of Perceived Risk and Variability[J]. Academy of Marketing Science. Journal, 1990, 18 (1): 51-65.

[11] Sheth J N, A Parvatiyar. Relationship Marketing in Consumer Markets: Antecedents and Consequences[J], Journal of the Academy of Marketing Science, 1995, 23 (4): 255-256. 